DOI: https://doi.org/10.46630/bs.3.2019.01

UDK 324(497.11 Пирот)

Вјекослав Бутиган ${ }^{1}$

Универзитет у Нишу

Филозофски факултет у Нишу

\title{
ОСМИ ВИШЕПАРТИЈСКИ ЛОКАЛНИ ИЗБОРИ У ОПШТИНИ ПИРОТ 2016.
}

\begin{abstract}
Резиме
Осми вишестраначки локални избори у општини Пирот показали су водећу позицију Коалиције за Пирот која је, уз два коалициона партнера, задржала власт у општини, трећи пут и успон Српске радикалне странке, која је освојила 3 одборника мање од Коалиције за Пирот. Број апстинената на изборима био је већи него на прошлим за 4,22\%.

Неравноправни услови за учешће учесника у изборима и већи број примедаба на регуларност избора показали су дефицит демократске политичке културе свих учесника у изборима од грађана до владајућих партија и група грађана.

Нарочито се види безобзирност у трговини одборничким манда тима у постизборним нагодбама у подели изборног плена, која је трајала преко две године и довела до преласка одборника Српске напредне странке и других из опозиције у владајућу већину. Тада је од 56 одборника само четири остала у опозицији, чиме је формални политички плурализам редукован на политички монизам у локалној самоуправи општине Пирот.

Кључне речи: локални избори, предизборна кампања, изборна апстиненција, одборници, градоначелник, изборна политичка култура.
\end{abstract}

\section{ДРУШТВЕНО-ЕКОНОМСКИ И ПОЛИТИЧКИ УСЛОВИ У КОЈИМА СУ ОБАВЉЕНИ ИЗБОРИ ЗА ОДБОРНИКЕ СКУПШТИНЕ ОПШТИНЕ ПИРОТ}

Председник Скупштине Србије Маја Гојковић расписала је локалне изборе у Србији 7. марта 2016. године и одредила 24. април за дан њиховог обављања. Обављени су по истом, већинском изборном систему као и прошли. Општине су биле јединствене изборне јединице. Осми вишепартијски локални избори за одборнике Скупштине општине Пирот одржани су истовремено са ванредним изборима за посланике Народне скупштине Републике Србије.

Међународни односи су погоршани грађанским ратом у Украјини, проглашењем Независне Доњецке Републике и присаједињењем Крима Руској Федерацији. Уследиле су међусобне санкције између Сједињених Америчких Држава и Европске уније на једној страни и Руске Федерације на другој страни. НАТО се шири према границама Руске Федерације. Гомилају се оружане НАТО снаге на њеним грани-

1 Butigan.pi@ sbb.rs 
цама, под изговором да НАТО тиме штити своје чланице од евентуал-

не руске агресије. Више угледних интелектуалаца упозоравало је да се свет креће ка трећем светском рату.

Спољна политика Србије се налазила пред великим изазовима због захуктавања хладног рата између Запада и Руске Федерације, њиховог психолошко-пропагандног и економског рата, у који су њихови актери настојали да увуку што већи број земаља, уз наговештаје претњи оружаним ратовима, како ниског, тако и високог интезитета. Глобални капитализам је од 2007. године у кризи и не преза да је и ратовима савлађује. На земаљској кугли водили су се неколико десетина ратова, најопаснијих по светски мир у Украјини, Сирији, Ираку и Либији.

Садашња Влада Србије је наставила политику претходних влада по формули „Европска унија и Русија и Кина“, уз упозорења ЕУ да неће моћи да настави такву политику као кандидат за њену чланицу. Наши „европски пријатељи“ већ 25 година систематски су радили на отимању српске покрајине Косова и Метохије, без икакве компензације за одузимање државне, корпоративне, приватне и личне имовине и огромних минералних, природних богатстава и културних добара на тој територији и уз лишавање Срба и других националности основних људских и грађанских права на Косову и Метохији. Ни ОУН преко УНМНИК-а, нити ЕУЛЕКС, испостава Европске уније на Косову и Метохији нису предузимали адекватне мере за повратак 250 000 становника протераних из својих станишта, нити за обезбеђење нормалног живота на поседима преосталих Срба и припадника других неалбанских народа. Оно што Запад није постигао "тврдом моћи“, бомбама, да се Србија одрекне од своје јужне покрајине, постиже „меком моћи“ - бриселским споразумима, мамцима и обећањима о отварању поглавља о испуњености услова за пријем Србије у ЕУ. Инсистирањем Запада да самопроглашена држава Косово буде примљено у међународне организације и институције завршава се његов наум да трајно обогаљи Србију, без Косова и Метохије.

НАТО се, после одбранбеног савеза, нападом на Југославију показао као агресивна војна организација која као ударна песница крчи путеве транснационалном капиталу ка земљама богатим енергентима, минералима, јефтином радном снагом и новим тржиштима. Поред Блиског истока устремио се на Русију, окружујући је својим оружаним снагама. Русија настоји да осигура своју безбедност јачањем својих оружаних снага и одвраћањем земаља које су јој наклоњене да приступе НАТО-у и тако постану непријатељске у евентуалном оружаном сукобу, борећи се за интересе водећих мултинационалних компанија, под патронатом Сједињених Америчких Држава. Искусивши „милосрђе НАТО анђела“, од чијих последица и данас умиру људи у Србији, апсолутна већина грађана Србије је против чланства у овој милитаристичкој организацији, упркос великој НАТО пропаганди и потрошеном новцу за придобијање Срба за прикључивање НАТО-у.

Напори Србије да успостави добре односе са суседима наилазили су на велике препреке. Нарочито су се тешко нормализовали од- 
носи са Хрватском, због многих нерешених проблема: са избеглим и прогнаним Србима из Хрватске, положајем српске мањине у Хрватској, рехабилитацијом усташтва, спорним границама са Хрватском и положајем хрватске мањине у Србији.

Велики број избеглица са Блиског истока преко Србије тражио је пролаз преко Хрватске за одлазак у Западну Европу. Хрватска је тражила од Србије да заустави избеглице пре њених граница, што Србија није могла да уради из више разлога. Због тога је Хрватска затворила границе за сва возила из Србије, а потом само за теретна да би јој онемогућила извоз роба на Запад. Настао је царински рат па је на интервенцију Европске уније морала да се укине та забрана. Хрватска je, као чланица Уније, покушала блокирање отварања поглавља 25 и 26 за приступ Србије Унији и тек на захтев водећих чланица Уније одустала је од њега.

У циљу помирења са Бошњацима у Босни и Херцеговини председник Владе Србије Александар Вучић ишао је на комеморацију жртвама сребреничког масакра у Поточарима и физички нападнут од групе Бошњака, 11. јула 2015. године. За то нико до сада није одговарао.

У протекле четири године Србија је била кандидат за пријем у Европску унију и отворила 8 поглавља од постојећих 35, у преговорима са Европском унијом од 2012. године, са условима које треба да испуни да би била примљена у Унију. Привремено је затворила два поглавља. Представници Владе Србије непрестано су понављали да је стратешки циљ Србије да постане чланица Европске уније, док су испитивања јавног мњења показивала да се из месеца у месец смањује проценат грађана који желе да Србија постане члан те Уније, када је Исланд прекинуо преговоре за улазак у Унију 2013. године, а Велика Британија се припремала за излазак из Уније. У Европској унији испољила се криза и са њом је растао евроскептицизам на Западу. Поред усаглашавања правних прописа са прописима Европске уније, остварења владавине права, људских слобода и права, искорењивања корупције, заштите мањинских права, развијања добрих односа са суседима, усклађивања привредног система са привредним системима чланица Уније, образовног, здравственог и културног система, Србија је једина имала поглавље 35 , које је обавезује да нормализује односе са Косовом, једнострано проглашеним за независну државу, „правно обавезујућим споразумом“, чији је садржај непознат.

У циљу нормализације односа са непризнатом државом Косово, коју није признало као самосталну државу 5 чланица Европске уније, Србија је водила преговоре са непризнатом државом Косово, у организацији Европске уније. Постигнута су два Бриселска споразума 2012. и 2015. између представника влада Косова и Србије којим је Србија учинила више уступака Косову. Предала је граничне прелазе Мердаре и Јариње на управљање косовским властима, укинула „паралелне структуре“ државе Србије: локалну самоуправу, безбедносне снаге, цивилну заштиту, судове. Предала је Косову енергетски и комуникациони систем, катастарске књиге, право на јединствен царински систем на целој територији Косова и Метохије. Дозволила је добијање 
међународног телефонског броја, укључивање у међународне и регионалне организације, организацију парламентарних и локалних избора власти према косовским законима на северу Косова и Метохије, са већинским српским становништвом...Тако је Косово заокружило суверенитет на целој територији Косова и Метохије, стављајући и северни део, са већинским српским становништвом, под своју контролу. Протерано 250000 Срба и других националности са Косова није могло да се врати у своје куће, станове и на своју имовину коју су узурпирали Албанци. Албанске власти на Косову и Метохији обавезале су се Бриселским споразумом 2012. да формирају Заједницу српских општина на северу Косова и Метохије и то ни после седам година нису учиниле под разним изговорима. Србија је до сада отплатила 650 милиона спољног дуга Косова и Метохије, учињеног од 1990. године и до 2025. године треба да се отплати још преко 300 милиона динара.

О нестабилности демократије у Србији најбоље казују подаци да је за последњих 27 година формирано 15 влада. Само су две владе деловале у пуном мандату: Мирка Марјановића и Мирка Цветковића. Највише су влада Србије формирали представници Социјалистичке партије Србије (6 и за последњих 12 година учествовали у седам влада). Једну владу формирала је Демократска странка Србије на челу са Војиславом Коштуницом, две владе Демократска странка, са Зораном Ђинђићем и Миодрагом Живковићем и три владе Српска напредна странка са Александром Вучићем као потпредседником и Ивицом Дачићем као председником, и по једну са Александром Вучићем и Аном Брнабић као председницима.

О учинку владе, у мандату између два избора, у вођењу унутрашње политике постоје две слике, једна лепша, коју приказују државни функционери а највише премијер, у медијима и друга, ружнија, коју грађани имају у свакодневном животу а исцртавају је на основу свога незадовољавајућег квалитета живота. Србија је споро излазила из рецесије, са најнижом стопом раста у региону, али уз оптимистичке прогнозе економског раста Међународног монетарног фонда и Светске банке, уколико настави са "болним реформама“, које нису подједнако болне за све. У 2015. години у Србији је 1,8 милиона становника живело на граници сиромаштва, сваки четврти становник. Са стопом од 24,6\% на граници сиромашних Србија је имала прво место у Европи. Следе је Грчка са $23.1 \%$, Румунија 22,6\%, Шпанија 22\% и Бугарска 21,2\%. Праг ризика од сиромаштва у 2012. години износио је 13.680 динара за једног члана домаћинства, за трочлано домаћинство 24.624 , за четворочлано домаћинство 28.728. Социјалну помоћ користило је 276.949 лица (srbijadanas.net).

Од 5-14. септембра 2015. године сарадници часописа Нове срnске политичке мисли, обавили су истраживање јавног мњења у Србији, на репрезентативном узорку за друштво Србије од 1.100 испитаника. Ранија слична истраживања ових сарадника показала су се веродостојним.

На питање "Како оцењујете тренутно стање у Србији оценама од 1-5?““, 29,8\% оценило га је незадовољавајућим оценом (1), оценом 
задовољава (2) 37,4\%, оценом добро (3) 27,5\%, врло добром (4) 5\%, и одличном (5) $1,4 \%$, средњом оценом 2,13, најнижом прелазном оценом, а иста таква оцена дата је и Влади Србије.

Половина ових испитаника (49,3\%) изјавила је да данас живи горе него пре три године, $32,8 \%$ да живи исто а $14,4 \%$ боље. Једна петина испитаника $(21,9 \%)$ тврдила је да је тадашња Влада гора од претходне (до 2012), 35,5\% да је иста, 36,7\% да је боља, (Вукадиновић, 2015). У ову групу од половине испитаника која живи горе улази и преко милион грађана са „привремено“ смањеним платама и пензијама, они који су изгубили посао или друге изворе прихода. У групи оних који живе исто су и они којима за три године нису повећане зараде, они који и даље не могу да нађу посао, којима су повећани трошкови живота, који не могу да отплаћују кредите, да школују децу...

Не очекује бољи животни стандард $32 \%$ у наредним годинама a $31 \%$ сматра да ће остати исти. Бољем животу се нада $27 \%$ испитаника. Они са траженим квалификацијама у иностранству одлазе из земља, нажалост, највише младих. Годишње 40.000 људи одлази из Србије у потрази за бољим животом.

У друштвеним делатностима, изузев у спорту, постоји стагнација или назадовање: у здравственој заштити, образовању, култури, док успон доживљава медијска шунд култура која уништава националну културу.

Демократска форма у јавном животу се све више испуњава ауторитаризмом и популизмом и добија обележја „фасадне демократије“.

У досадашњој сарадњи са ЕУ Србија је користила нека средства из претприступних фондова ЕУ, али је имала и штете, нарочито после непотребне либерализације увоза роба из ЕУ, која је скоро уништила домаћу индустрију и пољопривреду, јер нису могле да буду конкурентне својим производима оним из ЕУ. Пре него што су урађене студије о користи и штети које ће Србија имати уласком у ЕУ, политичари су прогласили да улазак у ЕУ нема алтернативу. Има европских земаља које се и ван ЕУ успешно развијају, које одустају од пријема у ЕУ. У Великој Британији вођена је политичка кампања за излазак из Европске уније (БРЕГЗИТ) која је завршена референдумом којим се већина грађана изјаснила за напуштање Европске уније. Србији су потребне научно утемељене стратегије за наредни најуспешнији развој, на основу којих ће се демократски определити којим путем треба да иде.

Комесари ЕУ говоре да пријем Србије у Унију зависи од испуњавања услова за пријем, међу њима и специјалних који се постављају само Србији, и доста штетних по њене националне интересе. Један од њих је потпуна нормализација односа са Косовом, правно обавезујућим документом, то јест добровољним одрицањем од Косова и Метохије, без икакве накнаде. Тражи се дистанцирање Србије од Руске Федерације и увођење санкција према њој. Њихов се списак сваке године увећавао, па изгледа да је пријем Србије у Унију недостижан, уколико она ЕУ уопште опстане оваква каква је, са великим уцењивачким капацитетом, недемократска, бирократизована и стварана по мери најмоћнијих држава Европе. 
Сједињене Америчке Државе су главни спонзор Косова као независне државе. На Косову имају највећу војну базу у Европи, више привилегованих компанија и стратешке државне интересе да контролишу путеве нафте од средњег Истока ка Европи. Западне земље су биле одлучиле да се Косово прими у УНЕСКО и преузме старање о српској средњовековној културној баштини и верским светињама које су паљене и уништаване у организованом мартовском погрому преосталих Срба и уништавање њихове имовине 2004. г. Снажном дипломатском акцијом Србије то је у последњем тренутку спречено, уз помоћ пријатељских земаља које нису гласале за то на Скупштинском заседању ове организације.

Ратови на Блиском истоку покренули су огроман талас од преко милион избеглица, највећим делом преко „балканске руте“ и Србије према Европи. Избегличка криза из бивших југословенских република 1991-1995. и са Косова 1999. која није много забринула Запад, јер ју је и изазвао, наговестила је будуће избегличке кризе из земаља Блиског истока у којима је Запад почео силом да уводи своју демократију. Србија, економским санкцијама и ратом НАТО-а осиромашена и скоро привредно уништена, трајно је збринула више од пола милина избеглица и расељених лица из бивше Југославије, а најбогатије земље Европе нису могле да нађу брзо и ефикасно решење за нешто више арапских избеглица, чију су несрећу изазвале. Настала је опасност распада ЕУ због несагласности о томе колико која чланица Уније треба да прими избеглица. Део избегличког терета пребачен је на балканске земље. Србија је збринула неколико хиљада избеглица, уз финансијску помоћ ЕУ. Запад није донео стратегију гашења ратних жаришта која су покренула избеглице ка Европи.

Србија, са искуством у збрињавању избеглица из деведесетих година, имала је више разумевања од чланица ЕУ за несрећне људе који су преживели рат и животно ризичан, дугачак пут ка Европи, и као осиромашена земља пружила им је онолико колико је могла да би имали снаге да наставе пут у „богате земље“.

Србија, почетком двехиљедешеснаесте године, није се битно променила од претходних локалних избора. И даље је била под патронатом Запада са штетним последицама по развој друштва и државе у Србији. У неоколонијалном статусу, премрежена разним канцеларијама Европске уније, Савета Европе, Савета за евроатлантске интеграције, НАТО-а, Међународног монетарног фонда, Светске банке, Европске банке за обнову и развој... и са преко 700 невладиних организација, претежно финансираних из иностранства била је под сталном контролом Запада. Са урушеним привредним системом и неолибералном економском политиком, заснованој на приватизацији, либерализацији, стабилизацији, привлачењу страних инвестиција уз велике субвенције, нуђење јефтине радне снаге и задуживање код међународних финансијских институција, Србија је била у рецесији из које је изашла тек 2015. године са позитивним растом од $0,8 \%$. Дезиндустријализација је изазвала пад друштвене производње, незапосленост, дефицит спољне трговине, макроекономску нестабилност, дефиците 
у спољној трговини, пораст задужености земаља у иностранству која је износила преко 26 милијарде евра. Велики буџетски дефицит успела је да смањи смањивањем плата у јавним службама и пензија већим од 25 000, од новембра 2014, у 2015, и 2016. години. Имала је најнижу стопу привредног раста у макрорегиону, најниже плате запослених, око 360 евра.

Смањен је број незапослених са 26\% на 17\%, највише превођењем радника из сиве зоне у легалне токове и исказивањем као запослених и оних који не примају плату, или им се не уплаћују доприноси, раде у сивој економији, сезонске и привремене послове и оних са непуним радним временом, без обзира на број радних сати ангажовања. Приличан број незапослених одселио се и запослио се у иностранству. У предизборној кампањи СНС је тврдила да је од прошлих избора запослено 120.000 нових радника (СНС информатор 38, март 2016).

Србију су, у мају 2014. године, захватиле велике поплаве, нарочито Обреновац и западну Србију, које су нанеле велике штете на стамбеним објектима, у пољопривреди и инфраструктури, што је било потребно санирати, уз велика средства. Поправљено је 200 километара путева, више мостова и изграђено 95 километара нових аутопутева, највише на коридору 10 (СНС информатор 38, март 2016).

Висок степен корупције није смањен. Против ње се водила више вербална борба. Спорне приватизације у 14 предузећа и поред инсистирања Европске уније нису разјашњене. Јавне набавке још представљају извор корупције. Сукоби интереса су веома чести у постављању руководилаца у јавним службама. Политичка корупција је највећа сметња за сузбијање корупције у другим областима друштвеног живота, нарочито у судству, државним и локалним органима, у здравству, образовању и тако редом. Инфлација лажних диплома доживела је невероватну експанзију против које се ништа није предузимало, јер су у поседу таквих диплома и неки утицајни политичари. Судски процеси су дуго трајали и оптужнице за неколико познатих тајкуна су застареле под сумњивим околностима.

Недостатак слободе медија и злоупотреба медија за постизање парцијалних политичких и економских интереса представљале су велику препреку у сузбијању корупције и демократизације друштва. Медијска политика је била персонализована од представника највише власти у држави. У годишњим извештајима Европске уније о напредовању Србије у испуњавању услова за пријем у Унију редовно је указивано да није достигнут потребан степен слободе говора и медија и да није смањена корупција.

Демографска кретања у Србији су забрињавајућа. У 2016. години било је најмање рођених беба у последњих 100 година. Те године умрло је 36100 више лица него што је рођено. Од 2006. до 2016. године само на основу смањеног природног прираштаја становништво је смањено за 385000 становника, са прираштајем од -5,1 промила, за 0,2 промила више него у 2015. години. Од 169 општина у Србији само је пет имало позитивни прираштај становништва: Нови Сад, Преше- 
во, Нови Пазар, Пријепоље и Тутин. У 2015. години 60.000 младих

образованих људи отишло је из Србије само у земље Организације за европску економску сарадњу и развој (Гречић, 2017).

Ивица Дачић, као председник Социјалистичке партије Србије до 1912. године, учествовао је у влади Демократске странке, као потпредседник и министар унутрашњих послова, а онда је од Српске напредне странке Србије добио понуду да са посланицима ове партије у Народној скупштини Србије и коалицијом Српске напредне странке формира владу као њен председник, са Александром Вучићем као првим потпредседником, и већином министара из изборне коалиције Српске напредне странке. Председнички и парламентарни избори 2012. године показали су успон Српске напредне странке, настале издвајањем једног дела кадрова и чланова из Српске радикалне странке. Те године њен кандидат Томислав Николић изабран је за Председника Републике Србије а коалиција Српске напредне странке освојила је највише посланичких места у Народној скупштини Србије, али недовољно да самостално формира Владу.

У Србији је било регистровано 118 политичких странака, скоро 6 пута мање него 2009. године. Од 1990. у Србији је обављано 15 изборних циклуса. Сваке друге године били су неки избори. Само 9 пута је вршен избор одборника, три пута је обављен референдум, па избор посланика и председника државе, тако да су 28 дана грађани били на биралиштима (Јовановић, Данас, 21. 2). Од 2012-2016. Србија је имала три парламентарна избора, два ванредна, иако за ванредне изборе није било објективних потреба. Били су потребни Српској напредној странци и њеном председнику да искористе свој политички рејтинг и преузму најважније државне функције у Србији. Тиме је успорен рад на неопходним реформама јер Народна скупштина није радила 16 месеци. За ванредне парламентарне изборе 2014. године потрошено је 1.970.004.238 динара и ванредне парламентарне изборе 2016. године 1.662.678.869 (Национална комисија за децентрализацију, 2017).

\section{ОПШТИНА ПИРОТ ИЗМЕЪУ ДВА ЛОКАЛНА ИЗБОРНА ЦИКЛУСА}

Тренд смањења броја становника општине Пирот настављен је. Процењени број становника у 2015. години износио је 55885 , мање 2 026 него пре четири године. Од тога 47.450 (84,95\%) становника било je ca 18 и више година. Фертилних жена 15-49 година било је 11.595 (20,75\%). Живо рођене деце било је 418 (7,5 промила, у Србији просечно 14,6). Природни прираштај у 2015. години био је мањи за 388 (-6,9 промила, у Србији просечно -5,3). Очекивано трајање живота у општини Пирот за мушкарце износило је 73,40 година, а за жене 79,29 година, нешто виши од републичког просека који је износио 72,62\% за мушкарце и 77,67 за жене. Умрло је 806 становника општине, више за 388 од броја рођених. Највише је умрло због болести система крвотока 472 (58,56\%), тумора 131, жлезда са унутрашњим лучењем 40, нервног система и очију 20. Просечна старост становника општине 
Пирот износила је 45,05 година, у Србији 42,72. Индекс старења износио је 175,7 (становници са 60 и више година подељено са оним од 0-19 година), у Србији 136,6.

У Пироту је живело 38.785 (66,95\%) становника и ван Пирота 19.141 (33,04\%), по попису 2011.

Највише је становника било од 15-65 година $36.704(65,68 \%)$. Најмање од 0-6 година, 2.967 (5,3\%) и 7-14 година 5.961 (6,77\%).

Остварене инвестиције у нове основне фондове по карактеру изградње износиле су 11.320.981.000 динара, 4,75 пута више него 2011, од тога у нове капацитете 6.383.604.000 динара, 60 пута више него пре 4 године, највише због повећања капацитета Компаније Тигар Тајерса. Ова компанија је извозила 90\% својих производа и била међу 5 највећих извозника у Србији. Са 295 милиона евра извоза била је у 2015. години трећи извозник у Србији. У производном програму имала је 2000 разних артикала. Ова компанија у саставу Мишелин групе има 500 инжењера разних струка.

Приходи и примања буџета по становнику износили су 17.911 динара а расходи буџета и издаци 17.858 динара по становнику, као и пре 4 године. У Србији приходи и примања буџета била су, просечно по становнику 34.581 динар, а расходи 34.526 динара.

Регистрованих запослених било је 14.495, мање 226 (1,55\%) него пре 4 године. Од тога први пут је тражило запослење 11.921 , више 240 него пре 4 године. На 1000 становника било је запослених 259 (у Србији 280). Највише запослених било је код правних лица (привредна друштва, предузећа, установе, задруге и друге организације) $11.921(82,24 \%)$, више за 1,65\%) него пре 4 године, код приватних предузетника 2.426 (16,73\%), мање 616 (4,26\%) него пре 4 године. Најмање је било запослених у групи регистрованих пољопривредника $148(1,02 \%)$. Највише је било запослених у прерађивачкој индустрији $5.665(39,1 \%)$, трговини на велико и мало и на поправци моторних возила $1.556(10,7 \%)$, здравству и социјалној заштити $1.263(8,7 \%)$, државној управи и обавезном социјалном осигурању 856 (5,9\%), образовању 804 (5,5\%), административним, услужним и помоћним делатностима 675 (4,7\%). Повећање запослених у последње 4 године остварено је у државној управи и обавезном социјалном осигурању за 385 (44\%) радника, у финансијској делатности и осигурању за 324 $(20,1 \%)$ и у саобраћају и складиштењу за 137 (24\%). У друштвеним делатностима највише је смањен број запослених у образовању за 183 (22,76\%) радника. У здравственој области радило је 215 лекара, стоматолога и фармацеута. Од 194 лекара 28 је био из опште медицине, 142 специјалиста, 24 лекара на специјализацији и 18 стоматолога. На једног лекара било је просечно 288 становника општине (у Србији 347). У апотекама је било запослено 25 фармацеута.

Просечна зарада, без пореза и доприноса, у општини Пирот била је у 2015. години 42.392 динара, у Србији 44.432 динара. У односу на 212. годину зараде су биле веће за $11,42 \%$.

Социјалну помоћ, као и пре 4 године, примало је 4.248 лица, а Народну кухињу користило је 850 лица. 
У општини Пирот било је 19.114 телефонских претплатника, 12 653 аутомобила, 63 аутобуса, 1.108 теретних возила, 46 радних возила, 1.303 прикључна возила (Гавриловић, 2016).

Општина Пирот од претходних локалних избора, 2012. године, имала је привредну стагнацију и депресију изражену у неколико параметара, али и известан напредак. Највећа Мишелинова (Mishelin) компанија Тигар Tajepc (Tyres) завршила је проширење и почетком 2016. примила 500 нових раднике тако да сада запошљава 3.000 радника (Стевановић, 2016). А.Д. Тигар се постепено опорављао. Слободна зона Пирот наставила је развој укључивањем страних компанија у рад у њој. Затворена Фабрика „Први мај“ још није била нашла свог власника, а некадашњи њени радници тражили су неисплаћене зараде. Скупштина општине Пирот је преко Фонда за развој пољопривреде давала новчана средства пољопривредницима за унапређивање пољопривреде.

У комуналном уређењу постигнут је напредак. Само у 2015. години асфалтирано је 40.000м2 уличних површина у граду. Изграђена је енергана, магистрални топловод и положене нове топловодне цеви: Изграђен је затворен базен и мост на другом рингу и обилазница око пиротског насеља од улице Српских владара до насеља Прчевац, средствима из буџета и уз финансијску помоћ Владе Републике Србије. Урађена је нова јавна расвета у неколико улица и део парка „Кале“.

Локална самоуправа у последњих 10 година остварила је успешну прекограничну сарадњу са општином Монтана, у Бугарској, у области инфраструктуре, реконструкције објеката образовања и културе. Остварила је 11 пројеката суфинансираних из инвестиционих претприступних фондова Европске уније у износу од 2 милиона евра. За показане резултате у тој сарадњи добила је 2016. признање ЕУ за реконструисање старе војне карауле у Планински дом, са 60 постеља, код села Дојкинци. Добила је из ових фондова 410 хиљада евра за реконструисање средњевековне тврђаве Кале и 200 хиљада евра за опрему породилишта Опште болнице у Пироту. Сарадња је проширена и у области привреде. Одржан је Форум привредника Пирота и Монтане 2014. године на коме су разматране мере за бољу размену роба и услуга две општине, боље коришћење фондова Европске уније за економски развој, кластерско удруживање, сарадња предузећа у овим општинама и нарочито коришћење повољности Слободне зоне Пирот за боље пословање.

Скупштина општине Пирот је имала уравнотежен буџет, са извесним суфицитом, што је постигао мањи број општина у Србији. Између владајуће већине и опозиције долазило је повремено до трвења на штету њеног успешнијег рада.

Почетком 2016. године општина Пирот добила је статус града и право на нову организацију градске управе са нешто већим овлашћењима и правима. После обављених избора 2016. године организација локалне самоуправе извршена је према одредбама Закона о локалној самоуправи у Србији, предвиђене за општине које су добиле статус града. 
Локална самоуправа је у последњем мандату постигла видне резултате у развоју инфраструктуре, подстицању пољопривредне производне, стварању бољих услова за развој Тигра, Слободне зоне, туризма, спота и рекреације.

Политичка структура Скупштине општине Пирот била је значајно промењена у постизборном периоду сталне борбе за промену власти, преласком одборника из једне политичке формације у другу, из групе грађана у политичке партије и обрнуто, из опозиционе у владајућу групацију и обрнуто, са сенком корупције.

Није постигнуто складно деловање владајуће већине и опозиције у циљу остваривања општих интереса грађана. Опозиција је игнорисана, прегласавана и када је била у праву, онемогућавана у свом деловању па је прибегавала опструкцији рада Скупштине да би скренула пажњу на свој неадекватан третман. Инаћење и доказивање ко је власт у општини, са елементима самовоље, наносило је штету ауторитету локалне власти, индиректно и свим грађанима.

Да је опозиција била у могућности да правовремено делује, не би било незаконитог трошења буџетских средстава, интервенције контролних органа и правосудских санкција за председника општине. Мање би било корупције.

Неадекватна сарадња челника општинске власти, из Коалиције за Пирот, са представницима органа Пиротског управног округа, из Српске напредне странке и лични анимозитети челника ових институција утицали су на игнорисање ауторитета једне власти од стране друге, на штету остваривања општих интереса грађана.

Пирот је 2015. године посетило 8.710 туриста, 4.453 домаћа и 4.257 страних. Они су остварили 19.658 ноћења, домаћи 9.339 и страни 10.319. Просечан број ноћења домаћих туриста био је 2,1 и страних 2,4.

Сеоски туризам показивао је прве резултате.

Јавна општинска предузећа су успешно пословала и инвестирала за проширивање капацитета пословања и побољшавање квалитета услуга грађанима и правним лицима.

У 12 објеката остваривано је предшколско васпитање деце са различитим трајањем.

У 33 школске зграде било је организовано основношколско образовање у 174 одељења, са 3248 ученика. Те године школовање је завршило 522 ученика.

У 5 средњих школа, са 79 одељења гимназију је похађало 502 ученика (завршило 137), четворогодишње средње образовање 1382 ученика (завршило 301), трогодишње стручне школе 226 ученика (завршило 77), са сметњама у развоју 162 (завршило 19).

У Високој школи струковних студија за образовање васпитача студирало је 212 студената, $189(89,15 \%)$ женског пола. На буџету је студирало 172 (81,13\%). У 2014. години дипломирао је 91 студент, од тога 88 женског пола и то 79 студије првог степена и 12 студената другог степена. 
Ученици пиротских школа доносили су признања и награде са републичких такмичења у знању.

Културне установе су успешно остваривале своју мисију, нарочито Народно позориште, Галерија „Чедомир Крстић“ и Народна библиотека.

Спортске организације су постизале видне успехе у раду.

Сви напред изнети друштвено-економски и политички услови и активности политичких делатника утицали су на изборно понашање појединих група бирача, њихову излазност и опредељивање за поједине изборне листе.

\section{ПРЕДИЗБОРНА КАМПАҢА}

Незванична предизборна кампања је почела и пре расписивања избора за локалне органе власти, током 2015. Правиле су се разне комбинације и калкулације за освајање гласова бирача. Политичке партије су се припремале за њих на свој начин. Није било предлога да се, после две и по деценије и седам изборних циклуса локалних избора, створе бољи услове за слободне, поштене и најрационалније изборе, са могућношћу да грађани изразе своју изборну вољу и контролишу рад својих изабраних одборника. А у случају њиховог незадовољавајућег рада и комерцијалног мењања партија и одборничких група да их опозову и замене другим. Главни актери на изборима биле су исте политичке партије, уз повремене и често привремене групе грађана, које су после избора губе везу са бирачима. Минорне, паразитске, партије скривајући се иза коалиција имале су шансе да се домогну мрвица власти, док за коалиције не буде повећан изборни цензус.

Постоји потреба да се темељно сагледају све врлине и мане досадашње изборне процедуре и њени исходи, уз широку расправу грађана и да се учини корак даље ка демократизацији ових избора. Међутим, политичке партије на власти не желе да се изврше изборне реформе јер им постојећи изборни систем омогућава да имају неке привилегије у изборној утакмици. Извештаји грађанима о раду одборника и функционера Скупштине општине Пирот у протекле 4 године били би обавезни.

У предизборну кампању за избор одборника Скупштине општине Пирот, ушло је 8 политичких групација, са осам изборних листа кандидата за одборнике: четири коалиције, три политичке партије и једна група грађана. У Србији је је било 216 регистрованих политичких партија, већином „метеорских“, активних само за време избора. Број изборних листа, већином коалиција, био је мањи за 3 него на претходним изборима, са само једним новим претендентом на локалну власт, Републиканском партијом.

Приликом пријављивања изборних листа било је и неких недостатака, који су накнадно отклањани. Републиканска странка је преко Уставног суда успела да издејствује регистровање изборне листе кандидата за одборнике као листе националне мањине, што је оспоравано од стране Општинске изборне комисије. 
Бирачима општине Пирот понуђене су одборничке листе: мр Владан Васић - Коалиција за Пирот у коју су, поред групе грађана, ушли: Нова Србија, Социјалдемократска партија Србије, страначке и нестраначке личности, са 56 кандидата за одборнике; коалиција Српске напредне странке Александар Вучић - Србија побеђује, са 56 кандидата за одборнике. У ову коалицију су ушли: Уједињена сељачка странка Србије, Покрет социјалиста, Партија уједињених пензионера и Покрет за Србију; Ивица Дачић - Социјалистичка партија Србије, са 56 кандидата; др Војислав Шешељ - Српска радикална странка, са 40 кандидата; коалиција професор Владица Тошић - победа за све, сачињена од Социјалдемократске странке и Либералнодемократске партије, са 27 кандидата; група грађана „Пиротска нова снага“ - Димитрије Видановић -Душан Митић са 38 кандидата; „За праведну Србију“ Демократска странка (Реформистичка странка - 33С), са 19 кандидата; Републиканска странка - Републиканус парт - Дамир Станиев, са 19 кандидата. Укупно је било на изборним листама 311 кандидата за одборнике, 145 мање него на претходним изборима. За једно одборничко место надметало се скоро 6 одборничких кандидата.

У предизборној кампањи на свакодневним конференцијама за медије, трибинама, наступима на локалном радију и локалној телевизији, у месним заједницама, одборнички кандидати, носиоци изборних листа, активисти политичких партија и група грађана, представљали су изборне програме и идеје које ће реализовати уколико буду изабрани за одборнике кандидати на њиховим изборним листама. Дељен је пропагандни материјал од стране предлагача изборних листа са већим новчаним средствима за кампању (Коалиција за Пирот, Српска напредна странка). Пошто су истовремено одржавани парламентарни избори у Пироту су се појавили скоро сви лидери политичких партија које су имале изборне листе, на митинзима, трибинама, на сусретима са грађанима.

Чланови Српске напредне странке лепили су своје изборне плакате преко билборда Коалиције за Пирот, па се мр Владан Васић обраћао преко медија „распуштеном Општинском одбору ове странке“ да прекине ове акције својих чланова а грађанима да их на изборима казне дајући своје гласове Изборној листи Коалиције за Пирот (Слобода 9. 4. 2016).

Један од представника групе грађана „Пиротска нова снага“ Димитрије Видановић тврдио је да су услови за политичке групације које нису у локалној или републичкој власти били веома нефер и некоректни и навео следеће чињенице:

Коалиција за Пирот (КЗП) и Социјалистичка партија Србије, вршећи власт у општини Пирот 14 година, имале су контролу над општинском управом и јавним предузећима. Управу су злоупотребили приликом прикупљања потписа грађана за подршку својим изборним листама, тражећи од запослених у јавним предузећима и установама потписе за своје изборне листе. Од великог броја спортиста, из клубова који су финансирани средствима из општинског буџета, као и чланова и активиста удружења грађана, која се финансирају на исти 
начин, тражена је подршка, уз напомену да уколико не подрже потписима листу КЗП, неће више добијати средства из буџета.

Приликом овере потписа грађана на изборним листама представници ових фаворизованих листа захтевали су од већине матичара и оверивача изборних листа да изврше оверу потписа на њиховим листама, па тек после на другим, хвалећи се како су у „рекордном року“, за два дана сакупили више потписа од потребног броја и одмах предали изборне листе да би се нашли на првим местима гласачких листића. Чак је коришћена база података у Дому здравља за добијање података о бирачима који су позивани да дају своје потписе за изборну листу предлагача СПС-а.

Велику предност приликом представљања свог политичког програма имала је КЗП у локалним медијима. Много већи простор и време у медијима имали су представници изборних листа на власти у односу на све друге. ,Чак су користили капацитете власти (општинске управе и јавних предузећа) за политички маркетинг у кампањи. Одједном су председник општине и директори јавних предузећа почели да „раде“, т ј. обилазе градилишта, школе, вртиће итд. што су медији морали да прате као редовне догађаје, што је опет довело у предност владајуће политичке групације“, навео је Димитријевић.

Коалиција за Пирот наступила је у изборну кампању са слоганом „Срцем за Пирот“, наглашавајући да она није под контролом неког центра политичке партије ван Пирота и да може самостално да доноси одлуке о развоју Пирота. Њени представници истицали су успехе локалне самоуправе у изградњи општинске инфраструктуре, пољопривреде, туризма, културе и спорта и добијање статуса Пирота као градске административне јединице.

Наговестили су да ће у новом мандату изградити ново постројење за пречишћавање отпадних вода, асфалтни пут до сваког села и сваке куће, увести осветљења улица и средити тротоаре. Тврђава „Кале“ ће се реконструисати. Свако насеље треба да добије дечје игралиште и спортски објекат.

Обећавали су да ће се уложити 100 милиона динара само у развој пољопривреде, посебно за развој индустрије, Слободне зоне Пирот и да ће стварати услове за отварање нових радних места преко финансирања јавних радова и самозапошљавања. Подстицаће локално предузетништво, уз подршку Тигар Тајерса, немачке организације „Хелп“ и породичног запошљавања.

Радиће на стварању најбољих услова за рад у информативно-телекомуникационом сектору, коришћењу капацитета Старе планине и коридора 10 за развој туризма.

У луксузно штампаном програму налазе се фотографије свих кандидата за одборнике. На билбордима је била слика носиоца листе са предизборним слоганом.

Јавна предузећа у општини укључила су се у предизборну кампању луксузно опремљеним Информатором, у коме су на 4 стране директори ових предузећа изложили резултате рада предузећа и планове за наредни период. На листи за одборнике био је и директор Јавног предузећа водовод и канализација. 
Локални лист Слобода објављивао је изјаве носилаца изборних листа, фотографије представника Коалиције за Пирот у обављању службених активности, уз обавештавање о њиховим посетама градилиштима, разговорима са станарима стамбених зграда о уређењу фасада, енергетској ефикасности, уређењу дворишта стамбених зграда и слично.

Српска напредна странка ушла је у предизборну кампању са привременим руководством-повереником странке за општину Пирот, jep је Општински одбор био распуштен. Њен предизборни слоган гласио је: „Хајде да уједињени мењамо Пирот набоље. Уједињени можемо све“. У предизборном програму навела је формирање нове индустријске зоне, са новим инвеститорима и новим радним местима, улагање 150 милиона динара у развој пољопривреде, повећање броја оваца и коза на 50. 000, крава на 15. 000 и подизање млекаре.

Предложила је обнављање сеоских амбуланти и покретних амбуланти, где их нема. Планирала је изградњу нове зграде хитне помоћи и набавку магнетне резонанце. Обећала је изградњу дома за старе и израду социјалне карате за социјално угрожене породице.

У оквиру Духовног центра радио би социјални саветник, а у омладинском центру саветник за младе.

Обавезују се да изграде модерни атеље са изложбеним простором, конференцијском салом и чак летњиковцем за сусрете уметника и публике, дечје позориште.

У луксузно штампаном програму налазиле су се фотографије у боји свих одборничких кандидата. И они су на билбордима имали заједничку слику председника странке Александра Вучића и Љубомира Стојановића, кандидата за градоначелника Пирота.

Српска Радикална странка истакла је слоган: „Пирот у сигурне руке“. На малом летку биле су исписане намере које има у развоју општине Пирот, уколико њихови одборнички кандидати добију поверење бирача. Међу њима су биле: обезбеђивање већих средстава и услова за самозапошљавање, кроз приватно предузетништво у пољопривреди, занатству и туризму. Оснивање фонда за лечење деце од ,тешких болести“, побољшање положаја трудница, помоћ социјално угроженим породицама и оснивање „сигурне куће“. Истиче намеру да реконструише улице, побољша јавну расвету, регулише одвођење отпадних вода, да оснује стамбену агенцију, премештање аутобуске станице и изградњу игралишта у насељима и селима. Изградила би дом пензионера а у селима домове културе.

Залагаће се за веће субвенције пољопривреди, уређење путева до обрадивих површина и отварање земљорадничких задруга.

Развијаће спортско-рекреативни, сајамски и сеоски туризам у циљу искоришћавања културно-историјског наслеђа Пирота и околине.

У циљу стварања бољих услова за васпитање деце радиће на повећању капацитета дечјих вртића за обухват све деце, бесплатно за децу из социјално угрожених породица, снимање доброг дечјег ТВ програма на локалним телевизијама и организовање „дечјег културног лета“". 
Радиће на стварању услова за запошљавање младих, изградњу аква и авантуристичких паркова, културног центра за младе и организовање великог броја културних манифестација за младе.

Сматра да Општа болница Пирот треба да прерасте у клинички центар, да се оснује служба спортске медицине, да се ослободе пензионери и хронични болесници партиципације за лекарске прегледе, да се обезбеди помоћ из буџета за вештачку и вантелесну оплодњу жена, набавку магнетне резонанце, укине Правилник о изабраном лекару.

Залаже се за отварање високошколских установа, медицинске, пољопривредне и туристичке школе, бесплатни превоз деце до школе и бесплатне уџбенике за децу незапослених родитеља.

У свим спортским клубовима ће се обезбедити бесплатни тренинзи за децу, стручно усавршавање тренера, помоћ из буџета свим аматерским клубовима и преузимање од града терена клуба „Прогрес“.

Пензионери би имали бесплатан превоз, културно-рекреативне програме и ,теренску бригу“ за изнемогле.

У оквиру заштите животне средине обезбедило би се: праћење загађености ваздуха и воде, уклањање дивљих депонија, уградња филтера код потенцијалних загађивача ваздуха и вода, уређење корита река и пошумљавање.

Српска радикална странка организовала је протесни предизборни митинг 1. априла на Тргу слободе у Пироту, на коме су говорили председник странке др Војислав Шешељ и највиши функционери странке. Митингу је присуствовало преко хиљаду људи (Слобода, 2. 4. 2016).

Социјалистичка партија Србије ушла је у предизборну кампању са слоганом „Дачић, СПС - до победе“, рачунајући највише на углед и утицај Ивице Дачића, председника странке, првог потпредседника Владе Србије и њеног министра иностраних послова. У недостатку финансијских средстава за кампању, користила је неплаћене наступе својих кандидата за одборнике на радију и телевизији и активисте у месним организацијама партије. Они су претежно понављали предизборни програм са претходних избора истичући левичарске пароле о бесплатном школовању, бесплатном лечењу, социјалној правди, заштити пензионера. Нудили су решавање комуналних проблема у насељима. Циљ им је био више да сачувају традиционалне бираче, него да придобију нове. Истицали су да са подмлађеним чланством могу да постигну боље изборне резултате него на прошлим локалним изборима. Организован је митинг на кому су наступили Ивица Дачић и његови најближи сарадници.

Група грађана Пиротска нова снага - Димитрије Видановић- Душан Митић имала је предизборни слоган: „Једини искрени за промене - Поштење је решење“. „Данас је у Пироту вредносни систем окренут наглавачке, па мање образовани и мање способни и неморалнији управљају образованијима, способнијима и моралнијима““ (Предизборни програм 1.) Њен предизборни програм изложен је у десет тачака.

У првој тачки се наводи да су досадашња буџетска средства трошена нерационално, да су одлазила у приватне џепове каналима корупције и криминала, што ће њени одборници спречити, уколико 
добију подршку грађана. Јер, без поштеног односа према новцу грађана нема правог развоја општине.

Указујући на то да се до сада практиковала имитација демократије и демократских институција нуди се бирачима „поновно успостављање и унапређивање урушених демократских институција и процедура одлучивања, система контроле трошења народних пара, јавност у раду и успостављање институција директног учешћа грађана у процесу доношења одлука. Скупштина ће бити место где ће се одлуке доносити кроз слободну и аргументовану расправу, где ће се уважавати опозиција и другачије мишљење и где ће моћи да седе заинтересовани грађани. Бићемо отворени за идеје и предлоге и формираћемо нестраначке грађанске савете од остварених стручњака и професионалаца““ (Предизборни програм).

Замерајући досадашњој локалној власти да није уважавала мишљење струке, због чега су извођени комунални радови лошег квалитета и наношена материјална штета, Пиротска нова снага залагаће се за поштовање професионализма, струке и ,успостављање нормалног систем вредности код одабира кадрова и процедуре одлучивања које подразумевају уважавање ставова грађана и стручњака, али и јасан систем одговорности“.

Бригу о породици и наталитету оствариће кроз помоћ свакој породици са више од троје деце, те на тај начин стимулисати позитивни природни прираштај становништва општине. Помагаће младим породицама, које своју будућност виде на селу, да купе земљу и започну сопствену производњу. С Симулисаће развој малих породичних предузећа кроз разне подстицаје и субвенције.

У оквиру локалног економског развоја општине Пирот одборници ове групе грађана основаће фонд за привредни развој општине, за финансирање пројеката привредника који могу да запосле нове раднике, уз обезбеђење инвестиција града и привредника. Субвенциониcaћe камате код комерцијалних банака за кредитирање увођења нових технологија и проширења производње ради запошљавања нових радника, као и зараде свих радника, нарочито радника са преко 28 година радног стажа и преко 55 година живота. Формираће савет за сарадњу са успешним Пироћанцима и Србима и у дијаспори за рад на унапређивању привредног развоја Пирота. Из јаке економије пристизаће средства за комунални развој општине.

За унапређивање пољопривреде ојачаће Фонд за развој пољопривреде, помоћи ће младим породицама да купе земљу, започну пољопривредну производњу и пласирају је на тржиште. Инвестираће у развој локалне прехрамбене индустрије, оживети градску млекару. Стимулисаће органску пољопривредну производњу и учешће младих у њој. А на Старој планини повећаће сточарску производњу.

Субвенционисаће се цене аутобуских карата у приградском саобраћају како би становницима села био доступан град а живот на селу прихватљив.

У очувању животне средине и природног простора пиротског краја, који треба да буде сачуван за будуће генерације Пироћанаца, 
залагаће се да Парком природе „Стара планина“ буде управљано по моделима најбољих европских пракси, које подразумевају учешће локалне самоуправе за економски развој општине и користи локалном становништву.

Залажући се за првенство примарне здравствене заштите радиће на стварању Дома здравља са специјалистичким службама у којима пацијенти без дугог чекања могу да приме здравствене услуге помоћу коришћења савремених информационих система. Што пре треба Хитној помоћи обезбедити адекватан простор за рад.

У циљу унапређења образовања и културе Пиротска нова снага стипендираће најбоље студенте, подржати стручно усавршавање просветних радника, допринети финансирању потребних образовних профила и финансирати примену савремене наставне технологије у образовним установама.

Радиће на промоцији правих културних вредности, очувању традиције нашег завичаја, даље развијати културне манифестације, организовати културну забаву за младе, без видео игрица пуних насиља.

Локалне телевизије, које се финансирају из буџета општине, биће обавезне да емитују квалитетне културно-образовне програме, у трајању од најмање једног сата дневно, у ударним терминима.

Уредиће простор и организовати културне манифестације и гостовања уметника у сеоским срединама.

У области спорта начиниће се заокрет од полупрофесионалног спорта ка масовном спорту и рекреацији грађана, ученика основних и средњих школа. Финансираће организацију квалитетне и потпуно бесплатне школе спорта која би трајала током целе школске године. Свим нашим кадетима, без изузетка, финансираће се сви нивои такмичења (од окружног, републичког, до европског и светског првенства) уколико се буду квалификовали.

Финансираће едукације свих наших тренера како би што квалитетније, у складу са свим светским стандардима, радили са нашом децом. Спортски центар ће бити обавезан да организује школска и општинска јуниорска такмичења у свим спортовима. Професионални спорт неће се потпуно финансирати из буџета. Мораће да финансирање потражи из других извора.

У сваком насељу ће се изградити спортски терени и дечије игралиште.

Коалиција: Социјалдемократска странка и Либерално-демократска партија имала је слоган „Победа за све СДС ЛДП““ и додатни „Чиста петица“.

Коалиција Демократска странка, Реформистичка странка - За праведну Србију, истакла је слоган „За поносан Пирот“. Скоро да се није видела у кампањи.

Већина предизборних програма имала је исте или сличне идеје, поред оних посебних. Неки програми су били маштовити и неостварљиви.

Изборна кампања је била изразито неравноправна у погледу материјалних средстава која су за њу коришћена у јавним наступима 
учесника предлагача изборних листа и кандидата за одборнике у медијима и коришћењу јавних ресурса локалне самоуправе.

Сви носиоци изборних листа са фотографијама и кратким одговорима на питање: „Како видите Пирот и живот у њему после избора“ нашли су се у локалном листу Слобода од 16. априла. Још једном су се појавиле слике или изјаве представника изборних листа Социјалистичке партије Србије и коалиције Социјалдемократске странке и Либералнодемократске партије. Два пута је Љубомир Стојановић, представник коалиције Српске напредне странке, представљен у службеним активностима у истом листу.

У листу Слобода највише простора имао је мр Владан Васић, носилац листе Коалиције за Пирот у службеним активностима.

У Слободи од 2. априла 2016. на насловној страни налази се фотографија председника општине мр Васића приликом уручивања уговора за десет стипендија најбољим студентима из Пирота. На другој страни се налази друга фотографија са исте свечаности са речима председника којима се обратио стипендистима.

У Слободи од 9. априла мр Васић се налази на фотографији на насловној страни, затим текст Васићеве изјаве на 3. страни о оштећењу билборда Коалиције за Пирот и на 4. страни фотографија са председником општине Монтана у Бугарској и краћом изјавом.

У истом листу 16. априла 2016. била је на насловној страни фотографија мр Васића приликом пресецања врпце и свечаног пуштања водовода у селу Понору. Иста фотографија са делом говора одржаном на тој свечаности одштампана је на другој страни овог листа. На истој страни дат је део изјаве мр Васића приликом обиласка незавршеног Планинског дома у селу Дојкинци, који су финансирали Скупштина општине Пирот и Европска унија.

На истој страни налази се и фотографија са отварања Јавног предузећа „Стара Планина“ у управи ХЕ Пирот на којој се налази њен директор и кандидат Српске напредне странке за градоначелника Љубомир Стојановић.

На 12. страни налазе се две фотографије мр Васића са отварања десетог појединачног, мушког шаховског првенства Србије, одржаног од 11-19. априла, на коме се види како повлачи први потез, чиме је првенство отворено. Том приликом мр Васић је поздравио учеснике и пожелео им пријатан боравак у Пироту.

Уочи гласања, у Слободи од 23. 4. 2016, 2 фотографије мр Васића нашле су се на другој страни, са амбасадором Сједињених Америчких Држава Кајлом Скотом и текстом о довођењу америчких инвеститора у Пирот. На 5. страни је фотографија мр Васића са предаје 87 уговора младим факултетски образованим Пироћанцима за обављање стручне праксе, јавних радова и других активности и текстом говора којим је поздравио присутне.

На 6. страни је слика мр Васића са предаје новчане помоћи 21-ој хранитељској породици од по 15000 динара, са краћим текстом обраћања присутним. На истој страни је фотографија мр Васића у разговору са станарком из насеља Чешаљ, после разговора са станарима о 
субвенционисању поправке фасада на стамбеним зградама. На истој страни је текст насловљен „Субвенције за почетнике у послу, посао за 28 особа“ у коме се мр Васић обраћа присутним приликом уручивања уговора о додељивању субвенција за запошљавање незапослених и за теже упошљавање особа са посебним потребама. На истој страни је фотографија мр Васића у разговору са мештанима приликом обиласка радова на асфалтирању кружног пута од Села Трњане до села Крупца. Тако је цела страна локалног листа Слобода испуњена активностима председника општине мр Васића.

На осмој страни Слободе је фотографија Васића са 32 спортиста, потписника уговора о стипендирању, са текстом којим се обратио присутнима.

Исте ове активности пропратила су и две локане телевизије и локална радио станица.

Тако су у време изборне тишине и престанка сваке предизборне кампање пре гласања, 23. априла, читаоци „Слободе“ на 4 стране листа имали 6 фотографија о разноврсним службеним активностима и седам изјава тим поводом председника општине Пирот и шефа Коалиције за Пирот. Овај лист за одређене програме добија средства из буџета општине Пирот. Председник општине и носилац изборне листе Коалиције за Пирот био је заступљен у овом листу више него сви остали носиоци листа заједно.

„Поруке, организације и лидери који нису присутни у медијима не постоје у јавном уму. Стога, само они који могу да пренесу своје поруке великом броју грађана имају прилику да утичу на њихове одлуке које ће их довести на позиције моћи у држави и/или помоћи да задрже свој утицај над политичким институцијама“ (Кастелс, 2014: 234).

\section{РЕЗУЛТАТИ ИЗБОРА ЗА ОДБОРНИКЕ СКУПШТИНЕ ОПШТИНЕ ПИРОТ}

Гласање за избор 56 одборника Скупштине општине Пирот обављено је на 86 бирачких места, 36 у граду и приградским насељима и 48 на сеоском подручју.

У бирачке спискове било је уписано 49.126 бирача, 1.324 мање него на претходним изборима (2012). Гласало је 29.463 (59,97\%), 2.654 мање него на прошлим изборима. Није гласало 19.649 бирача $(40,03 \%)$, на претходним $18.066(35,81)$. Број апстинената на изборима је већи него на прошлим изборима за 4,22\%.

Излазност на локалне изборе у Србији износила је 56,42\%.

Број неважећих листића био је 1.038 (3,52\%) и са оним који нису гласали, приближава се половини $(43,55 \%)$ бирачког тела, што смањује демократски легитимитет изабраних одборника и оних које ће они бирати, скоро за половину.

Све изборне листе су добиле 28.419 (96,45\%) гласова, од броја гласалих, а од укупног броја кандидата за одборнике, изабрано је само $18,01 \%$. 
Коалиција за Пирот освојила је највише гласова 10.562 (37,17\%) и $23(41,07 \%)$ одборничка мандата у Скупштини општине. На прошлим изборима имала је 10.549 (33,87\%), Освојила је само 13 гласова више него на претходним изборима и исти број одборничких мандата (23). Имала је малу предност са 868 (3\%) гласова више од коалиције Српске напредне странке. Већи проценат освојених гласова за 3\% на овим изборима последица је смањене излазности бирача и мањег броја изборних листа. Овај резултат остварила је успешном презентацијом свог досадашњег рада, ефикаснијом и дуготрајном кампањом, комбинованом са службеном активношћу и коришћењем локалних ресурса за кампању, као вршиоца досадашње локалне власти. Већину гласова освојила је на бирачким местима у граду и делом у приградским насељима. Коалиција за Пирот је четврти пут на овим изборима потврдила свој доминантни изборни статус. Изборна снага ове групе грађана у коалицији са две политичке партије, мерена односом освојених гласова према броју укупног бирачког тела, износи $21,40 \%$.

Коалиција за Пирот била је најуспешнија по проценту освојених гласова у односу на број кандидованих одборника у износу од 41,07\%. То је трећи по висини коефицијент остварен у Пиротској области.

Коалиција Српске напредне странке остварила је 9.881 (34,07\%) глас и 21 одборнички мандат. Од броја предложених кандидата за одборнике изабрано је 37,50\% и са тим процентом учествовала је у структури Скупштине општине. Овај успех постигнут на локалним изборима остварен је захваљујући већем броју коалиционих партнера, великој популарности Александра Вучића и гласовима највећег броја пензионера. На овим изборима остварила је више за 3.181 глас $(13,09 \%)$ и 11 мандата, него на претходним изборима. На прошлим изборима имала је 4.778 (15,38\%) гласова и 10 мандата. Пиротски напредњаци добили су тада 1.725 (5,55\%) гласова и 3 мандата. Укупно су две колоне Напредњака оствариле 6.500 гласова. Изборна снага ове петочлане коалиције на овим изборима била је 21,11\%.

Српска напредна странка наступила је самостално на локалним изборима у Белој Паланци и Димитровграду. У Белој Паланци имала је изборну листу са 29 одборничких кандидата и добила 5.781 глас (76,03\%). Тиме је освојила 82,76\% од кандидованих одборника и апсолутну већину од $82,76 \%$ одборничких мандата у Скупштини општине. То је највећи коефицијент изабраних од предложених кандидата у Пиротској области.

У Димитровграду са 18 кандидата за одборнике освојила је 2.904 (45,11\%) гласа и 14 одборника, 48,28\% од кандидованих одборника и са тим процентом има одборничке мандате у Скупштини општине. То је други по величини коефицијент изабраних одборника у Пиротској области.

У Бабушници, у коалицији са Српским покретом обнове, на изборној листи имала је 23 кандидата за одборнике. Освојила је 1.170 $(15,39 \%)$ гласова и $5(21,74 \%)$ мандата и са истим процентом учествује у Скупштини општине.

Социјалистичка партија Србије освојила је 2.722 (9,58\%) гласа и 5 одборничких мандата, 8,93\% од предложених одборника и са истим 
процентом учествује у Скупштини општине. Њена изборна снага изно-

си 5,54\%. На прошлим изборима, у коалицији са Партијом уједињених пензионера Србије, добила је $3.548(11,42)$ и 7 одборничких мандата. С обзиром на невидљиву кампању, очекивања да ће јој Дачић донети гласове и одсуство прошлог коалиционог партнера ПУПС-а, остварила је добар резултат, који много заостаје иза прве две изборне листе. Остварила је $826(1,39 \%)$ мање гласова од листе за посланике, али више гласова за посланике остварен је и уз гласове симпатизера Јединствене Србије, с којом је ова партија била у предизборној коалицији.

Социјалистичка партија Србије је самостално изашла на избоpe у општини Бабушница, са 23 кандидата и освојила 1.344 гласа, $(16,65 \%)$ и 5 одборничких мандата $(21,74 \%$ од предложених) и са истим процентом одборника учествује у Скупштини општине.

У Белој Паланци наступила је у коалицији са Јединственом Србијом. Њихова изборна листа имала је 29 кандидата за одборнике и добила је 1.170 (15,39\%) гласова, 5 одборника (17,4\% од кандидованих) и са $17,4 \%$ одборника чини Скупштину општине Бела Паланка.

У Димитровграду наступила је самостално са 29 кандидата и освојила 404 (6,41\%) гласа и 2 одборника, 6,90\% од кандидованих и толико мандата у Скупштини општине Димитровград.

Социјалистичка партија Србије је са 108 предложених кандидата за одборнике остварила у Пиротској области укупно 4.470 (9,03\%) гласова, 12 одборничких мандата $(8,76 \%)$ и у четири скупштине има $11,1 \%$ одборника.

Група грађана Пиротска нова снага - Димитрије Видановић- Душан Митић освојила је $1.891(6,65 \%)$ глас и 4 одборничка мандата, $10,52 \%$ освојених од броја кандидованих одборника и са 7,15\% одборника учествује у Скупштини општине. Изборна снага ове групе грађана je 3,84\%. Има мање од половине гласова освојених на претходним изборима и пола одборничких мандата мање, када је наступала са две групе грађана и две изборне листе. Постизборни маневри ПНС-а после 2012. године и аранжмани са СНС-ом (прикључење одборницима Српске напредне странке и издвајање од ње) нису наишли на одобравање њихових бирача. Пре 4 године ПНС имала је 2.253 (7,25\%) 4 мандата а Душана Митића Покрет за Пирот 1.994 гласа (6,26\%) и 4 мандата. Спајање 2 групе грађана показало се неуспешним јер су изгубиле 4 мандата.

Коалиција Владица Тошић Социјалдемократска странка, Либералнодемократска партија, освојила је 1.614 (5,68\%) гласова и 3 мандата, $11,11 \%$ од броја предложених кандидата и 5,35\% учешћа у Скупштини општине. Предлагачи изборне листе за посланике истих странака добили су 4,88\% гласа. Мали број ових одборничких мандата имао је одлучујући утицај на формирање изборне већине и конституисање Скупштине општине и њених извршних органа.

Социјалдемократска странка самостално је изашла на локалне изборе у Бабушници са изборном листом од 23 кандидата и остварила 420 (5,83\%) гласова и добила 1 одборнички мандат, 4,35\% од броја предложених кандидата за одборнике и са тим процентом учествује у Скупштини општине Бабушница. 
Коалиција: Реформистичка странка, Заједно за Србију -Демократска странка освојила је 537 (1,89\%) гласова. Највећи губитник на овим изборима је била Демократска странка, јер са коалиционим партнером није прешла изборни цензус. Она је на прошлим изборима, у коалицији са Социјалдемократском партијом имала $2.758(8,82 \%)$ гласова и 5 одборничких мандата. Чинила је изборну већину у Скупштини општине. Затим је дошло до издвајања једног дела одборника из одборничке групе који је прешао у опозицију.

Српска радикална странка је остварила 1.149 (4,04\%) гласова. Показала је слабији резултат на овим изборима за 218 гласова $(0,36 \%)$, него на прошлим и поново није прешла изборни цензус. Прошли резултат био је $1.367(4,40)$ гласова и 0 мандата. Дуже одсуство са политичке сцене, масовни прелазак њених чланова у Српску напредну странку и негативна предизборна капања умањила јој је број гласова па није успела да пређе цензус. Није прешла изборни цензус ни у суседним општинама Пиротске области.

Испод цензуса је била Републиканска странка Дамира Станијева, као мањинска, са 283 (0,93\%) гласова, деведесетак више од броја потписника изборне листе.

„Бачени“ гласови ове три странке у износу од 1.949 приписани су осталим странкама које се прешле изборни цензус, сразмерно освојеним гласовима.

У изборној политичкој култури на овим изборима има минималних помака.

После расподеле мандата члановима коалиција у Скупштину општине Пирот ушли су представници петнаест политичких партија (међу њима и прозелити, са више промењених партија) и две групе грађана. Неким одборницима је ово четврти мандат у скупштинама општине Пирот, у неколико сазива. Највише је одборника Коалиције за Пирот који су четврти пут били изабрани за одборнике.

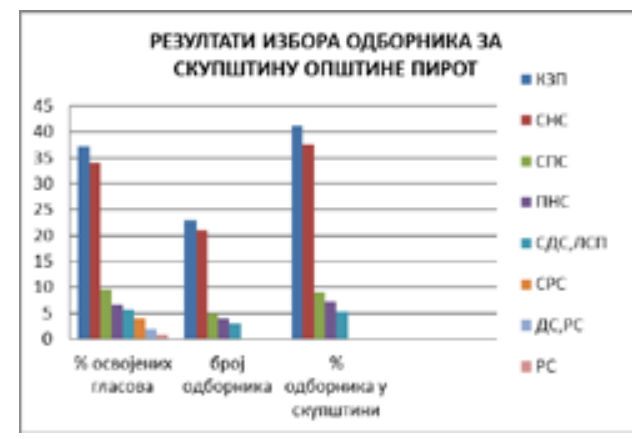

КЗП - Коалиција за Пирот; СНС - Коалиција Српске напредне странке; СПС - Социјалистичка партија Србије; ПНС - Пиротска нова снага СДС, ЛДП - Коалиција Социјалдемократске странке и Либералнодемократске партије; СРС - Српска радикална странка; ДС, РС Демократска странка и Реформистичка странка; РС - Републиканска странка. 


\section{НАРОДНЕ СКУПШТИНЕ РЕПУБЛИКЕ СРБИЈЕ И ЗА ОДБОРНИКЕ СКУПШТИНЕ ОПШТИНЕ ПИРОТ}

За посланике Народне скупштине Републике Србије од 49.156 бирача уписаних у бирачке спискове у општини Пирот гласало је 29.496 (60\%) бирача. Неважећих гласачких листића било је 763 (2,59\%). За изборну листу коалиције Српске напредне странке, Александар Вучић - Србија побеђује, гласало је највише бирача 17.818 (60,75\%), више за $8.137(25,93 \%)$, од изборне листе за одборнике ове коалиције.

Велика разлика у броју освојених гласова коалиције СНC-а на локалним и републичким изборима настала је због ширег састава ове предизборне коалиције на републичким изборима, па су за посланичку листу коалиције Српске напредне странке гласали чланови и симпатизери: Српског покрета обнове, Коалиције за Пирот, групе грађана и други, који нису имали своје кандидате за посланике.

Изборна листа коалиције Социјалистичке партије Србије и Јединствене Србије за посланике Народне скупштине Србије добила je 3.235 (10,9\%) гласова, мало више од изборне листе само Социјалистичке партије Србије на локалним изборима.

Коалиција: Либералнодемократске партије, Лига социјалдемократа Војводине и Социјалдемократска странка добила је 1.439 $(4,88 \%)$ гласова, мање скоро за један проценат од изборне листе за локалне изборе и то без присталица Лиге социјалдемократа Војводине.

Изборна листа Српске радикалне странке добила је 1.916 (6,49\%) гласова за посланике, нешто више него на локалним изборима.

Коалиција: Либералнодемократске партије, Лига социјалдемократа Војводине и Социјалдемократска странка добила је 1.439 $(4,88 \%)$ гласова, мање скоро за један проценат од изборне листе за локалне изборе и то без присталица Лиге социјалдемократа Војводине.

Изборна листа Српске радикалне странке добила је 1.916 (6,49\%) гласова за посланике, нешто више него на локалним изборима.

\section{КОНСТИТУИСАҢЕ СКУПШТИНЕ ОПШТИНЕ ПИРОТ И СКУПШТИНЕ ГРАДА ПИРОТ}

Изменом Закона о територијалној организацији Србије у Народној скупштини Србије, 27. фебруара 2016, која је ступила на снагу 9. марта, општина Пирот је добила статус града, као територијално-административне јединице, пошто је испунила економске, инфраструктурне, културне и политичке услове за то. Иницијатива за добијање статуса града Пирот настала је Петицијом коју је потписало 7000 грађана општине Пирот 2009. године. У време обављања локалних избора Пирот је имао статус општине па је било потребно прво конституисати Скупштину општине Пирот, а затим да та Скупштина донесе Статут града Пирот и да се према том статуту конституише нова Скупштина града Пирот. 
У преговорима око формирања скупштинске већине учествовали су сви предлагачи изборних листа. Коалиција за Пирот и Српска напредна странка нису могле да постигну договор око подела функција у Скупштини и извршној власти, због ,превеликих захтева Српске напредне странке“, како је изјавио Милан Поповић, које Коалиција за Пирот није могла да прихвати. Међу тим захтевима био је и да Љубомир Стојановић буде изабран за градоначелника. Како је Коалиција за Пирот још 15. марта 2015. године постигла протоколарни договор са Социјалистичком партијом Србије и Социјалдемократском странком о сарадњи у вршењу власти, лако је формирана скупштинска већина од 31 одборника, за које је гласало 14.898 (50\%) бирача и 30\% од укупног бирачког тела. Опозициони блок чинили: су Српска напредна странка и Пиротска нова снага са 25 одборника и истим бројем добијених гласова бирача као и владајућа већина.

Конститутивна седница Скупштине општине Пирот одржана је 16. маја 2016. године.

На седници Скупштине усвојени су извештаји Општинске изборне комисије, и Верификационе комисије Скупштина је једногласно верификовала мандате изабраних одборника.

Приликом усвајања дневног реда конститутивне седнице Скупштине општине Пирот одборник Димитрије Видановић, у име опозиције, предложио је да се пре конституисања Скупштине прво донесе Правилник о раду Скупштине града, у складу са њеним Пословником и да се одложи усвајања Статута града Пирот за наредну седницу, како би могли да предложе амандмане на предлог статута, усвојеног од стране претходног Општинског већа. Већина од 31 одборника није прихватила предлог. Истом Већином за председника Скупштине општине, на предлог одборника Коалиције за Пирот, изабрала је Милана Поповића, коме је ово четврти узастопни мандат. Одборници Српске напредне странке и Пиротске нове снаге бојкотовали су гласање за председника Скупштине општине. Већином од 33 гласа (уз 2 гласа одборника Пиротске нове снаге) усвојен је Статут града Пирот чиме су створени услови за конституисање Скупштине града Пирот. Одборници скупштине општине Пирот, у складу са тим Статутом, добили су статус одборника Скупштине града Пирот.

Конституисање Скупштине града Пирот обављено је на седници 27. маја. На њој је гласовима 31-ног одборника скупштинске већине изабран за председника Скупштине града Пирот Милан Поповић, из Коалиције за Пирот, Владица Тошић, за заменика председника Скупштине, из Социјалдемократске странке, Драган Јовановић за секретара скупштине, мр Владан Васић, за градоначелника, из Коалиција за Пирот и Видојко Панајотовић, за заменика градоначелника града Пирот, из Социјалистичке партије Србије. Опозициони одборници бојкотовали су гласање јер Скупштина није усвојила Записник са претходне седнице, нити је усвојила њен предлог да се не усваја Статут града на претходној седници, већ на наредној, да се прво донесе Правилник о раду Скупштине града и нови Пословник о раду нове Скупштине, па онда бирају извршни функционери. 
У складу са Статутом града одборничка већина изабрала је Градско веће од 9 чланова (више за 2 од броја који је био раније у Општинском већу) које чине: 5 из редова Коалиције за Пирот, 2 из Социјалистичке партије Србије; 2 из Социјалдемократске партије Србије, 1 из Либералнодемократске партије. По функцији чланови Градског већа су градоначелник и његов заменик.

Скупштина је усвојила оставке одборника који су изабрани за градоначелника, његовог заменика и чланове Општинских већа и верификовала мандате одборника који су их заменили.

Градоначелник Пирота је својим решењем 3. јуна именовао 5 помоћника градоначелника Пирота у складу са Статутом града и коалиционим договором са Социјалистичком партијом Србије и коалицијом Социјалдемократске странке и Либерално демократске партије и то: 3 помоћника из Коалиције за Пирот, 1 из Либерално-демократске партије и 1 из Социјалистичке партије Србије.

Формирањем одборничких група, шест скупштинских радних тела, комисија и Градског већа конституисана је Скупштина града Пирота. После нешто више од годину дана дошло је до промена у извршној власти Скупштине града.

\section{СТРУКТУРА ОДБОРНИКА СКУПШТИНЕ ГРАДА И СКУПШТИНЕ ОПШТИНЕ ПИРОТ 2012.}

У Скупштини града Пирот преко половине одборника 30 $(53,57 \%)$ је било од 40-59 година а најмање 7 (12,50\%) је било између 18-29 година.

Слична је ситуација и у Србији, јер преко половине одборника $(54,28 \%)$ имало је између 40 и 59 година. и најмлађих 18-29 година $8,62 \%$ (Илић и др, 2017).

У Скупштини општине Пирот изабраној 2012. године три четвртине одборника, 42 (75\%) било је 40-59 година, најмање 3 (5,36\%) шездесет и више година.

У поређењу са старосном структуром одборника у Србији и Југоисточној Србији Скупштина града Пирот има процентуално више одборника 18-29 година и са 60 и више година, а мање у групи 30-39 година и 40-59 година.

Стално пребивалиште у граду има 45 (79,36\%) одборника, а 11 $(19,64 \%)$ у селима и то: 3 у Извору, по 2 у Крупцу, Гњилану и Петровцу и по 1 у Пољској Ржани и Темској. Сви они запослени су у Пироту.

С обзиром да једна трећина становника општине Пирот живи у селима изборна геометрија се показује неповољном за сеоско становништво, нарочито у брдско-планинским пределима општине. Она показује да једно село, Извор, са 595 уписаних бирача има три одборника, док суседно, Бериловац са 636 бирача нема ни једног, као ни остала 64 села

Један мањи број одборника станује у приградским насељима.

Од 56 одборника Скупштине града Пирот две трећине, 37 $(66,07 \%)$ је мушког пола а 19 (33,92\% женског, што је у оквиру за- 
конског одређења родне структуре одборника локалних скупштина у Србији. Најмање је изабрано жена са листе коалиције Српске напредне странке $28,57 \%$ а највише са листе Социјалистичке партије Србије $60 \%$.

Број жена у Скупштини града Пирот је изнад просечног броја жена у локалним скупштинама Србије. У Србији је на овим локалним изборима изабрано $31,2 \%$ жена за одборнике, у Југоисточном региону Србије 30,4\%.

На локалним изборима 2012. године у Скупштини општине Пирот било је 14 (25\%), жена, у Србији 28,6\% и Југоисточној Србији $27,8 \%$.

Највише одборника женског пола је од 30-59 година. Најмање је жена 18-29 година 2 (3,57\%).

Највећи број одборника Скупштине града Пирот $26(46,42 \%)$ има високо образовање, 12 (21,42\%) средње образовање, 8 (14,28\%) више образовање, 4 (7,14\%) има школу за квалификоване раднике, 4 $(7,14 \%)$ има звања специјалиста и магистра и $2(3,57 \%)$ доктора наука.

У Скупштини града Пирот има више одборника са специјализацијом и магистратуром 3,57\%, са високим образовањем 3,57\% и $5,36 \%$ са вишим образовањем, него у Скупштини општине Пирот пре четири године.

Скупштина града Пирот има одборнике са високим и вишим образовањем, специјалисте и докторе наука изнад просека у општинским и градским скупштинама Србије.

Две трећине одборника Скупштине града Пирот, 35 (62,50\%), су стручњаци разних профила. Следе функционери и руководиоци 6 $(10,71 \%)$, техничари и сарадници $6(10,71 \%)$, руковаоци машинама 3 $(5,35 \%)$, пензионери $3(5,35 \%)$ и 2 студенти (3,57\%). Међу стручњацима највише је инжењера $11(19,64 \%)$, професора и васпитача 10 $(17,85 \%)$, лекара 7 (12,70\%), дипломирана правника 2 (3,57\%), дипломирана економиста $2(3,57 \%)$ и 5 других занимања $(26,78 \%)$. У Скупштини града је 6 стручњака више него у Скупштини општине Пирот 2012. године.

У поређењу са професионалном структуром скупштина општина и градова у Србији Скупштина града Пирот има двоструко више стручњака разних профила од просека у Србији. Мање је техничара и стручних сарадника за близу 5 процената од просека у Србији и мање пензионера око 2\%. У осталим занимањима одборници Скупштине града Пирот су око просека у Србији.

За разлику од скупштина општина у Србији међу одборницима Скупштине града Пирот нема истакнутих привредника, запослених у пољопривреди, индустријских радника, занатлија и сродних занимања.

\section{ГРАДОНАЧЕЛНИК ПИРОТА}

У 4 општине Пиротске области изабрано је 137 одборника. У избору председника 3 општине и једног градоначелника учествовало 
је 129 одборника. За њихов избор гласало је 100 одборника 77,5\%. Два председника општине кандидовао је СНС, једног СНС и СПО и једног група грађана. Кандидати СНС-а добили су приликом гласања 40 гласова (42\%). Кандидат СНС-.а и СПО-а добио је 23 (24,5\%) гласова. Градоначелник Пирота изабран је са 31-ним гласом (33\%) од укупног броја гласалих одборника у области Пирот и 56\% гласова одборника Скупштине града Пирот.

Од 166 председника општина и градоначелника у Србији 6 $(3,14 \%)$ је доктора наука, 24 (14,45\%) магистара и специјалиста, 99 $(59,63 \%)$ са високом стручном спремом, $3(1,80)$ са вишом и $1(0,60 \%)$ са средњом школском спремом. У Југоисточној Србији било је 12 председника општина и градоначелника магистара и специјалиста а међу њима је и градоначелник Пирота мр Владан Васић.

У Србији су 124 председника општина и градоначелника били по занимању политичари, или како их статистика исказује: законодавци, функционери, руководиоци-менаџери. У Пиротској области са таквим занимањем била су 2 председник општине, 1 градоначелник, а само је један председник био стручњак. Мр Владан Васић је на ту функцију дошао као политичар.

Преко две трећине 112 (67,46\%) председника и градоначелника у Србији су били животне старости 40-59 година. Међу њима су у Пиротској области и 3 председника општине и један градоначелник мр Владан Васић. Градоначелник Пирота мр Владан Васић је пре избора на ову функцију 3 пута био биран на функцију председника општине Пирот и на њој провео 14 година.

\section{ПРОМЕНЕ У СТРУКТУРИ ОДБОРНИКА И ИЗВРШНОЈ ВЛАСТИ СКУПШТИНЕ ГРАДА ПИРОТ ПОСЛЕ ИЗБОРА И КОНСТИТУИСАЬА ВЛАСТИ}

Српска напредна странка потписала је коалициони споразум са Коалицијом за Пирот о заједничком деловању 27. јуна 2017. године. Са 21-ним одборничким мандатом постала је део одборничке већине од 52 одборника у Скупштини и добила представнике у извршној власти града, два члана Градског већа и једног помоћника градоначелника. У опозицији су остала само 4 одборника.

На сеници Скупштине града 30. јуна са 45 гласова одборника разрешена су 3 члана Градског већа из Коалиције за Пирот и 1 из Либералнодемократске странке. Уместо њих тајним гласањем изабрани су три нова члана, два из Српске напредне странке и 1 из Коалиције за Пирот. Потом је уместо једног члана Коалиције за Пирот, за помоћника градоначелника именован 1 члан из Српске напредне странке. Ове промене представници ових коалиционих партнера објаснили су тежњом за постизањем стабилније одборничке већине, боље везе са најјачом политичком партијом у Србији, тиме са Владом Србије и већим могућностима да заједнички раде на унапређивању Пирота.

Шеф одборничке групе „Пиротска нова снага“, тим поводом изјавио је да су још у предизборној кампањи указивали да ће сви учес- 
ници у изборима, сем "Пиротске нове снаге“, у погодном тренутку ући у извршну локалну власт. „Хтели смо да укажемо грађанима да ће бити преварени, јер су многи глумили опозицију и то се десило. Пиротска нова снага је једина права опозиција и то ће до крај остати“ (Слобода, 1. јул, 2017, 2. стр.).

Овом променом опозиција у Скупштини града сведена је само на 4 одборника и скоро хомогенизована, под влашћу једне велике политичке коалиције.

Седам чланова Српске радикалне странке, који су били кандидати за одборнике ове странке на прошлим локалним изборима, на челу са дотадашњим председником Окружног одбора Пирот и чланом Главног одбора странке прикључили су се Коалицији за Пирот, незадовољни односом своје дотадашње странке према њиховом раду у Пироту. Они су то учинили ,да би се укључили у остварење бројних пројеката за бољи живот у Пироту“, саопштено је на конференцији за новинаре (Слобода, 10. јун 2017).

Ове политичке партије примениле су етички споран политички принцип: „Ако не можеш да победиш противника, приступи му.“

Лидер Коалиције за Пирот мр Владан Васић честитао је овој групи најактивнијих некадашњих радикала на укључивање у Коалицију за Пирот и позвао све који желе добро своме граду да се укључе у рад Коалиције за Пирот. „Коалиција за Пирот је увек била тачка окупљања политичких снага и појединаца са ауторитетом који не припадају политичким партијама“" (Слобода, 10. јун, 2017, 2. стр.).

На конференцији за новинаре, крајем јуна, челници Српског покрета обнове обавестили су да су на проширеној седници Општинског одбора странке донели једногласну одлуку да се колективно припоје Коалицији за Пирот. Навели су да су у протеклих 13 година били у коалицијама са Коалицијом за Пирот и да ,желе да са њом раде на остварењу пројеката за бољи живот грађана“ (Слобода, 24. јун 2017, 5. стр).

На конференцији за медије одржане у Медија центру Дома културе 7. марта 2018. године, представник Општинског одбора Либералнодемократске партије у Пироту саопштио је да је Општински одбор ове странке донео једногласну одлуку да се припоје Коалицији за Пирот а њихов одборник у Скупштини града одборничкој групи ове коалиције. Истовремено је објављено да је и део Социјалдемократске странке у Пироту приступио Коалицији за Пирот а њихов одборник одборничкој групи Коалиције за Пирот. Тиме се распала предизборна коалиција Социјалдемократске странке и Либералнодемократске партије а Коалиција за Пирот је добила 25 одборника у Скупштини града Пирот, од укупно 56 одборника. „Лидер КЗП-а, градоначелник мр Владан Васић изражавајући задовољство јачањем коалиционог потенцијала КЗП-а, позвао је и друге политичке опције да се придруже КЗП-у“ (Слобода, 10. март, 2018, стр. 2.). На насловној страни „Слободе“ и испод овог обавештења у њој је фотографија на којој је за столом, поред нових партијских конвертита, градоначелник мр Владан Васић и његов заменик, а иза њих стоје чланови Коалиције за 
Пирот, директори: Музеја, Дома културе, Водовода и канализације, Дома здравља и други угледници ове коалиције, чиме се шаље кадровска визуелна порука потенцијалним конвертитима на каријерне могућности које нуди Коалиција за Пирот.

Ни у једном случају напуштања политичких партија на чијој листи су одборници бирани није указано да се тиме крши члан 4 „Етичког кодекса понашања носиоца јавних функција локалне самоуправе града Пирота“ о поштовању изборне воље бирача: "Поштујући избор бирача, а нарочито ако је изабран са страначке листе кандидата изабрани функционер локалне самоуправе треба да избегава да током свог мандата промени странку којој је припадао у време избора.“

Две године после локалних избора у Србији 472 одборника у 91ној општини променило је партију на чијој листи су изабрани чиме је изневерена изборна воља 56000 грађана (СРТА, 2018).

На седници Скупштине града 23. марта 2018. године саопштено је да су четворица одборника са листе Српске напредне странке СНCа и да су они формирали нову одборничку групу „Најбоље за Пирот“. Одборник Зоран Петровић, са листе СНC-а поднео је оставку на одборничку функцију „из моралних разлога“, то јест због искључења четири одборника из странке и одборничке групе CHC-a. Уместо њега верификован је мандат другог одборника. Тако је одборничка већина смањена за четири одборника и сведена на 48 одборника (Слобода, 24. март 2018. и Пиротске вести).

\section{ИЗБОРНА ПОЛИТИЧКА КУЛТУРА У ОПШТИНИ ПИРОТ 2016.}

Политичко стање у општини Пирот оптерећено је хроничним недостатком демократске политичке културе главних актера политичких збивања у политичким институцијама локалне самоуправе, у политичким партијама и код бирача. „Демократски дефицит неизбежно је праћен растом ауторитарног суфицита скривеног али и отвореног у деловању... великих корпорација и медија“ (Видојевић, 2015:472). Политика се код приличног броја носилаца политичких функција схвата као уносан бизнис за њих и чланове њихових породица, у времену тешког доласка до добро плаћеног сталног радног места. Зато неки хрле у политичке партије пре него у завод за тржиште рада и сопствени бизнис. Уз то, сматра се да је у политици све допуштено, посебно ако постоји заштита у органима власти по слогану „Буди наш, па ради шта знаш“. Многи политику остварују као вештину лагања, варања, лажног представљања, фалсификовања, злоупотребе положаја и манипулације људима, за остваривање личних и групних интереса.

Политички престиж се доказује омаловажавањем, вређањем, клеветањем, неоснованим оптужбама, исмевањем, игнорисањем политичких противника, злоупотребом ауторитета политичких вођа, па и бруталним насртајем на морални и физички интегритет политичких противника, да би се не само победили у надметању за освајање власти, него да би се политички и морално уништили. Прокламовани 
„Етички кодекс носилаца јавних функција у општини Пирот“ крши се без икаквих санкција.

Како је демократски предзнак основна политичка легитимација сваког политичког субјекта а гласови већине пресудни у избору на политичке функције и у одлучивању, већински принцип се апсолутизује као једини, или најважнији принцип демократије и демократског понашања, заборављајући све остале: људска права, слободе, владавина права, уважавање и слободно деловање опозиције, поштовање изборне воље грађана, рад у интересу грађана, политичка партиципација грађана, подржавање критичке јавности, економски обезбеђени, слободни и одговорни медији, као четврта грана политичке моћи...

Постоји велики дефицит у демократским политичким дијалозима, толеранцији, компромисима, поштовању личности противника, у иницијативама и партиципацији грађана у доношењу важних за њих одлука. Нема помака у унапређивању локалне демократије да од посредне и представничке постане народна демократија у којој грађани преко грађанских иницијатива, референдума, зборова грађана, петиција, јавних расправа и консултовања, учешћа грађана у раду радних и саветодавних тела и других форми непосредног одлучивања о условима свога живота.

На резултате локалних избора, поред утицаја ауторитета партијских лидера и носилаца изборних листа на бираче, имали су и рад са људима на терену, садржај и начин вођења предизборне кампање, добри изборни програми а нарочито квалитет кандидованих одборника, или фамилијарне, пријатељске, пословне, спортске, комшијске и друге везе кандидата за одборнике у локалној средини. Посебан утицај имала је пројекција личности кандидата за одборнике у свести бирача у медијима и профилисан њихов имиџ. Они кандидати који су највише били заступљени у медијима имали су највише шанси да буду изабрани.

Учешће самосталних група грађана на изборима било је најмање, јер су оне имале неравноправне и најнеповољније услове за освајање локалне власти, како законске, тако и материјалне, медијске, организационе и друге. У постојећем пропорционалном изборном систему групе грађана имају мале изгледе на успех.

Усталила се пракса у Србији да у предизборним политичким кампањама не постоје равноправни услови за надметање политичких партија и група грађана, нити се учесници у њима придржавају законских норми и правила етичког кодекса носилаца јавних овлашћења.

Мада је циљ предизборне кампање да се бирачи упознају са предизборним програмима учесника у изборима и кандидатима који треба да их реализују, неки од њих нису доступни бирачима. Претежно се воде лидерске предизборне кампање, маркетиншки обликоване. Оне су повезане са функционерским активностима у локалним срединама у којима се јавни ресурси користе у страначке сврхе. Лидери општина и градова користе своје функције за промоцију својих изборних листа.

Закон о спречавању сукоба интереса при вршењу јавних функција прописује радње које су забрањене функционеру. У чл. 6 пише 
да му је забрањено ,... да би на било који начин интересно погодовао себи или другом“ а у тачки 1 истог члана ,да је забрањено и да стекне ново или оствари постојеће право за себе или другог, ако тиме крши једнакост грађана пред законом“.

У чл. 10 ставу 2 Етичког кодекса понашања носиоца јавних функција локалне самоуправе општине Пирот пише: „Кандидат неће тежити да прибави гласове на било који други начин осим убедљивом аргументацијом“ у изборној кампањи, а у ставу 3 „Посебно, кандидат неће покушати да прибави гласове ... злоупотребом функције коју обавља нити пружањем или обећавањем противуслуга“. У чл. 7 забрањује се сукоб интереса: „Функционер локале самоуправе неће вршити своје дужности, односно користити овлашћења свог положаја у циљу остваривања својих личних или групних интереса““. А у чл. 11, ставу 3. пише: „Локални функционер ни у ком случају неће користити службена средства или имовину за потребе своје изборне кампање“.

Недемократску праксу у изборима осудила је група стручњака Канцеларије за демократске институције и људска права Мисије Организације за безбедност и сарадњу (ОЕБС) у Србији у завршном Извештају за процену председничких избора 2017. у Србији и изнела препоруке за превазилажење недостатака у изборном току. Она је констатовала да је предизборном кампањом „доминирао кандидат владајуће коалиције, истовремено и премијер, којем је ишло у прилог нејасно разграничење између активности које је спроводио као део изборне кампање и оних које је обављао као премијер.“ ... "Већина медија је о кампањи извештавала пристрасно, при чему су садржајем доминирале теме о активностима владајуће структуре, нарочито премијера... РЕМ није користио своја законска овлашћења за надзирање политичког садржаја који се приказује у електронским медијима, нити је деловао да спречи неизбалансирано извештавање које су забележиле организације цивилног друштва...Нарочито распрострањени, и потврђени од стране неких саговорника били су наводи о вршењу притиска на запослене у државним институцијама и институцијама повезанима с државом да пруже подршку господину Вучићу, али и обезбеде додатну подршку на начин да то пренесу свима осталима, и подређенима и члановима породице и пријатељима“ (НСПМ). Ова група је препоручила „да је потребно строго поделити активности које су државничке и оне које су страначке и придржавати се те поделе“ и створити механизме „како би се обезбедио ефикасни правни оквир у случају кршења изборних права“" (НСПМ).

Ова оцена групе стручњака Мисије Организације за европску безбедност и сарадњу у Србији може се дати и локалним изборима у општини Пирот 2016. године, због изборне капање у којој је учествовао премијер Александар Вучић у парламентарним изборима као носилац листе за избор посланика и чије је име било у називу Изборне листе коалиције Српске напредне странке за избор одборника у Скупштини општине Пирот. Поред Српске напредне странке у овој кампањи доминирала је Коалиција за Пирот мр Владана Васића. На то је указивано и на прошлим локалним изборима у Пироту. 
Годинама и деценијама се то понавља а да се ништа не предузима да се спречи. То показује да Србија није демократски уређена држава.

О финансирању учесника изборне кампање на локалним изборима јавност није обавештена. Агенција за борбу против корупције Републике Србије је поднела захтев тужилаштву да истражи сумњиве уплате 2.400 људи, међу њима и лица која добијају социјалну помоћ, по 40.000 динара уплаћених на име донација Српској напредној странци за изборну кампању 2014. године. Број таквих донатора за кампању Српске напредне странке за председничке изборе повећао се 2017. на 7.000 лица. Сумња се да се ради о прању новца нелегално добијеног од рекетирања локалних привредника, или сумњивих јавних набавки. У тој кампањи Српска напредна странка потрошила је 800.000.000 динара, 25 више од трошкова другопласираног кандидата Саше Јанковића, 300 пута више од трећепласираног Луке Максимовића и три пута више од четвртопласираног Вука Јеремића (Стојиљковић, 2017).

У недостатку грађанске политичке културе одржава се поданичка политичка култура, у којој власт прописује разне обавезе својим становницима, лишавајући их могућности остваривања људских и грађанских слобода и права. Уместо тежњи за демократском политичком културом одржава се демократска политичка некултура. Политички морал остао је без хуманих политичких вредности и политичких врлина, што кореспондира са стањем друштвеног морала и његових вредности. Јер, и грађанске врлине су недовољно развијене, што омогућава бујање политичке и сваке друге врсте корупције.

Политичка култура политичких партија је утилитарно-клијентекистичка чији је основни циљ користољубље њених руководилаца и чланова. Због тога већина њих жели по сваку цену да буде на власти и преко ње оствари материјалне користи и разне привилегије. Зато неће да буде у опозицији. У опозицији неће имати никакве материјалне користи а биће изложени разним врстама омаловажавања и понижавања. Таква политичка пракса политички плурализам у организацији локалне самоуправе своди на интересни политички монизам удружених партијских вођа.

Четрнаест година на челу локалне самоуправе у општини Пирот био је мр Владан Васић. Томе је допринела и његова политичка култура у којој се истиче: „Ја сам у свему тражио логику. И дан данас тражим логику у најједноставним стварима. Да ли су то одлуке које предлажемо Већу или Скупштини, или су неке веће одлуке, свеједно. И тада сам тражио логику у људима и међу људима, у њиховим размишљањима и деловањима... да трагамо за суштином, јер често људи од много детаља не виде суштину и циљ који треба постићи“ (Слобода 2017: 5). Сматра да поштује договоре, не мења одлуке док се не договори другачије, брзо размишља и брзо доноси одлуке кад то диктира ситуација, уважава туђе мишљење, истрајава до краја у науму, уме да изабере добре сараднике, уз мање грешке.

„Осамнаест година учешћа у власти и четрнаест година владавине Пиротом перспективног дипломираног инжењера електротехни- 
ке, запосленог у рачунарском центру Индустрије одеће „Први мај“, „претопиле су у професионалног политичара““ (итал. В. Б.) (Слобода, 2017: 5).

Градоначелник Пирота мр Владан Васић је говорио о „својој четрнаестогодишњој и владавини Коалиције за Пирот градом“ у интервјуу датом „Слободи“. Интервју је завршен констатацијом: „рекао је градоначелник Владан Васић, на крају нашег разговора о уласку Коалиције за Пирот у општинску власт и континуитету њене и његове владавине Пиротом од 2003. до данашњих дана“ (Слобода, 16. 12. 2017). „И да углавном имам увид у целокупно функционисање читавог система власти“ (Слобода,30.12.). У овим интервјуима мр Владан Васић је три пута тврдио да је владао Пиротом, мада у Закону о локалној самоуправи и Статуту општине Пирот нигде не пише да је право председника општине и градоначелника да влада општином и Пиротом, већ су прецизно наведени послови које треба да обавља у оквиру извршне власти, да са одговарајућим органима остварује функције локалне самоуправе предвиђене Уставом, Законом о локалној самоуправи, Статутом општине/града и другим правним актима.

Коалиција за Пирот никада није формално сама вршила локалну власт, већ је имала и коалиционе партнере. Ти партнери су били важни у конституисању локалне власти, а по изјави градоначелника они су били искључени из „владања Пиротом“. Они су били задовољни руководећим положајима на које су били постављени и свим оним што уз то следи.

Мада су у Србији обављена 15 циклуса избора у последњих 27 година најмање се радило на побољшању изборне политичке културе. Политичке мисије ОЕБС-а, Цесид-а и ЦРТ-е указују на неправилности у понашању свих учесника у изборном процесу: бирача, политичких партија, кандидата за одборнике, изборних органа, изборне администрације, учесника у изборним кампањама и медија. Због тога избори нису довоњно демократски, ни слободни, ни поштени.

\section{ЛИТЕРАТУРА}

Видојевић, Зоран. Пораз и алтернативе, претьа пустоши и етика отпора. Београд: Завод за издавање уџбеника, 2015.

Вукадиновић, Ђорђе. Истраживање - Србија у јесен 2015. www.nspm. rs. (приступљено 31. 10. 2015).

Гавриловић, Душан, уред. Општине у Србији 2016 (исправљено издање 23. 3. 2017). Београд: Завод за статистику Републике Србије, 2017.

Гавриловић, Душан, уред. Општине у Републици Србији. Београд: Завод за статистику Републике Србије, 2016.

Гречић, Владимир. „Прошла година рекордна по исељавању из Србије. У земље ОЕЦД емигрирало 58000 из Србије“. Политика 4. октобар 2016.

Илић, Биљана и Милош Мајкић, припр. Локални избори 2016. Коначни 
резултати избора. Београд: Завод за статистику Републике Србије, 2017.

Јовановић, Милан. „Политичке партије не желе изборне реформе“. Данас 16, 2018.

Информатор о раду јавних предузећа Пирот, 2016.

Кастелс, Мануел. Моћ комуникација. Београд: РТС издаваштво, Мултимедија Клио, 2014.

СНС информатор, Уједињени можемо све. Београд: Гласник Српске напредне странке 38, март 2016.

Национална комисија за децентрализацију. Највише Вучићевих средстава током кампање отишло за Пинк и Блиц (приступљено 6. 7 . 2017). Доступно на: www.nspm.co.rs

Предизборни програм у 10 тачака (локални избори 2016). Пирот: Пиротска нова снага.

Степановић, Јелена. Интервју са Миленом Тошић, директором службе подршке у Компанији Тигар Тајерс, 2016 (приступљено 17. 4. 2017). Доступно на: www.B92net.

Стоиљковић, Зоран. Тврдња Вучића о финансирању Српске напредне странке нису тачне; Агенција за борбу против корупције има јак доказ, али не верујем да ће оптужница бити покренута, 2017 (приступљено 6. 11. 2017). Доступно на: www.nspm.co.rs.

Стручњаци Канцеларије за демократске институције и људска права ОЕБС-а представили су у петак завршни извештај мисије за процену председничких избора у Србији и изнели препоруке за превазилажење недостатака у изборном току (приступљено 4. 11. 2017). Доступно на: www.nspm.co.rs.

Панчић Миленковић, Каја. „Преживели смо велике политичке буре. Градоначелник Владан Васић о својој четрнаестогодишњој и владавини Коалиција за Пирот (интервју). Слобода 16. 12. 2017, стр. 5.

Панчић Миленковић, Каја. „Личним печатом мењате професију, али и професија мења вас. Градоначелник Владан Васић о себи пре уласка у политику и свакодневници првог човека града (интервју). Слобода, 30. 12. 2017, стр. 5.

П. В. „Пиротски СПО се колективно припојио Коалицији за Пирот“. Слобода 24. јун 2017, стр. 5.

В. Ћ. „СНС по први пут улази у локалну власт“. Слобода 1. јул 2017, стр. 3.

К. П. М. „Ново јачање КЗП-а““. Слобода 10. март 2018, стр. 2.

К. П. М. „Седница Скупштине града и Градског већа“. Слобода 24. март 2018, стр. 2.

К. П. М. „Додељено 14 општинских студентских стипендија“. Слобода 2. април 2016, стр. 2.

Р. С. „Радикали увек говоре истину“. Слобода 2. април 2016, стр. 3.

A. Ћ. „Васић: Наш билборд је затворени базен, нови мост, Кеј поред 
Нишаве“. Слобода 9. април 2016, стр. 3.

П. В. „Међусуседска сарадња“. Слобода 9. април 2016, стр. 4.

П. В. „Село понор добило воду. Општина уложила преко 20 милиона динара“. Слобода 16. април 2016, стр. 2.

Р. С. „Пирот домаћин појединачног шаховског првенства у шаху. Десети шампионат окупио 8 велемајстора“. Слобода 16. април,2016, стр. 12.

А. Ћ,, Р. С, П. В. „О активностима градоначелника Пирот“. Слобода 23. април 2016, стр. 1, 2, 3, 5 и 6.

ЦРТА (Центар за истраживање, транспарентност и одговорност). Последње две године утростручен број страначких „прелетача“ након локалних избора, 472 одборника изневерила изборну вољу 56.000 гласача (приступљено 24. 4. 2018). Доступн на: www.nspm.co.rs.

\title{
THE EIGHTH MULTI-PARTY LOCAL ELECTIONS IN THE PIROT MUNICIPALITY 2016.
}

\begin{abstract}
Summary
The eighth multi-party local elections in the Pirot municipality showed the leadership of the Coalition for Pirot, which, with two coalition partners, retained power in the municipality, for the third time and the rise of the Serbian Radical Party, which had three 3 councilors less than the Coalition for Pirot. The number of abstainers in the elections was $4.22 \%$ higher than in the past.

The unequal conditions for the participation of the participants in the elections and the increasing number of objections to the regularity of elections showed the deficit of political culture democratical of all participants in elections from citizens to ruling parties and groups of citizens.

Particularly seen is the inconciderate in the trade in parliamentary seats in the post-election ditribution of the election' s booty, which lasted for over two years and led to the transition of councilors of the Serbian Progressive Party and others from the opposition to the ruling majority. At that time, of the 56 councilors, only four remained in opposition, reducing formal political pluralism to political monism in the local government of Pirot municipality.
\end{abstract}

Key words: Pirot local elections, election campaign, electoral abstinence, councilors, mayor, political culture electoral. 